\title{
CONSIDERATIONS ON THE INTERNATIONAL REGULATIONS RELATING TO THE SANCTIONING OF ACTS HARMING THE ENVIRONMENT
}

\author{
D. Ș. Paraschiv
}

\author{
Daniel-Ștefan Paraschiv \\ *Correspondence \\ Ph.D. Lecturer - Faculty of Law \\ "Spiru Haret" University \\ e-mail: drept_vl.paraschiv.daniel@spiruharet.ro
}

\begin{abstract}
Even if international law manifested initially as quite reluctant in the acceptance and, especially, the massive international liability for environmental damage, since the second half of the twentieth century were adopted several international legal instruments of general and special nature which include regulations on environmental protection measures, but also on the liability of those guilty of altering it.
\end{abstract}

\begin{abstract}
Key words: environmental protection, international conventions, illegal acts, liability, sanctions
\end{abstract}

\section{Introduction}

One of the basic principles of international law is the idea that any breach of an engagement involves an obligation to repair ${ }^{1}$.

International Responsibility represents an essential institution of public international law that establishes what consequences arise for an entity as a result of the breach of an international obligation $^{2}$, representing also the mechanism through which is obtained the restoration of legality - if the legal order is disregarded by a state or another subject of public international law ${ }^{3}$.

Permanent degradation of the natural environment causes particularly complex environmental problems, manifested by lack of harmony between the man-made and natural environment ${ }^{4}$, leading not only to the destruction of the ecological balance, but also the reverse reaction ${ }^{5}$, environment becoming less favorable for the realization of socio-economic activities, human life 6 , which can no longer be considered the center of the biosphere ${ }^{7}$.

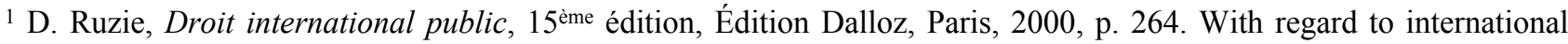
jurisprudence, the Permanent Court of International Justice stressed that "it is a principle of international law and even a broader conception of law, that any breach of an engagement involves an obligation to fix", namely Factory at Chorzów (Germany V Poland), Judgment of July 26, 1927, PCIJ, Series A, no. 9 (http://www.icjcij.org/pcij/serie_A/A_09/28_Usine_de_Chorzow_Competence_Arret.pdf), p 29; in the same sense, see the case Corfu Channel (United Kingdom of Great Britain and Northern Ireland against Albania), Judgment of December 15, 1949, ICJ Reports 1949 (http://www.icj-cij.org/docket/files/1/1663.pdf), p 263

2 D. Popescu, Felicia MAXIM, Drept internaţional public, Renaissance Publishing House, Bucharest, 2010, p. 322.

${ }_{3}^{3}$ P.-M. Dupuy, Droit international public, 7 ème édition, Dalloz, Paris, 2004, pp. 457.

${ }^{4}$ I. Mihuț, Autoconducere şi creativitate, Dacia Publishing House, Cluj-Napoca, 1989, p. 259.

${ }_{5}^{5}$ M.-L. Larsson, The Law of Environmental Damage: Liability and Reparation, Martinus Nijhoff Publishers, The Hague, 1999, p. 39.

${ }^{6}$ I. Avram, D. Şerbănescu, Mediul înconjurător al Terrei încotro?, in RRSI, No.1, January-February 1989, page 32,
} 


\section{CONSIDERATIONS ON THE INTERNATIONAL REGULATIONS RELATING TO THE SANCTIONING OF ACTS HARMING THE ENVIRONMENT}

Faced with these realities people should be aware of future dangers, and states must work together to establish internationally the best measures to protect and improve the environment, which includes not only the material and organizational efforts, but also the development of scientific concepts to this new attitude towards the environment, based on the reconciliation of man with nature ${ }^{8}$.

International law remains quite reluctant to the acceptance and especially materialization of the idea of international responsibility of States for environmental damage.

Moreover, legal regulations do not impose an absolute prohibition in certain areas to pollute, authorizing actually a reasonable pollution?.

There have been and are done substantial efforts to adapt to the peculiarities of environmental protection action and the gradual building of a form of liability for harm to the environment ${ }^{10}$.

\section{International regulations on environmental protection and liability for acts affecting it}

Legal liability for acts affecting environment is normative, as in other areas, which cannot exist without a legal requirement, be it legal rules of compliance or legal rules to sanction a conduct considered illegal, the purpose of this liability is the preservation of the social values in the field ${ }^{11}$.

As required by law as a punitive measure against those who committed the unlawful act, liability is triggered in order to sanction and reeducate and restoring the rule of law infringed ${ }^{12}$.

Legal liability in environmental law has little impact and has many features ${ }^{13}$, the main objective being to prevent degradation as environmental damage is usually permanent, irreversible or difficult to control and to assess and the cost of restoring the affected environment (where possible) becomes exorbitant and does not give a full and effective reparation ${ }^{14}$.

Public international law does not contain sufficient provisions for the punishment of acts that harm the environment, but were adopted, however, several international instruments aimed at environmental protection, such as the Declaration of Principles of the United Nations Conference on the Human Environment (1972), Rio de Janeiro Declaration (1992), Johannesburg Declaration (2002), Convention on long-range Trans boundary air Pollution (1979), Convention on the Protection of the Ozone Layer (1985), Convention on Biological Diversity (1992), the Framework Convention on Climate Change (1992), Convention on the law of the Sea (1982), Convention on the relative right to use international watercourses for purposes other than navigation (1997), Convention on the Control of trans boundary Movements of Hazardous Wastes and their elimination (1989).

\footnotetext{
which shows that the planet's fertile land turns into desert, and the disappearance of many species of plants and animals can lead to the inability to find cures for some serious diseases that kill tens of people daily.

${ }^{7}$ L. K. Caldwell, International environmental policy: Emergens and dimensions, Second Edition, Duke University Press, Durham, 1990, p. 3.

${ }^{8}$ N. N. Constantinescu, Protecţia mediului natural - cerinţă intrinsecă a unei dezvoltări economice moderne, in,,Economistul”, no. 180 of 3-6 April 1992, p. 5.

${ }^{9} \mathrm{P}$. Lascoumes, La justice de l'environnement industriel: une place à predre et à inventer, in „Justice”, no. 122, novembre 1988, p. 33, which states that "The problem was originally thought (political) and built (legal) as an administrative management of a number of risks and injuries. The police established an administrative device, which is more incentive than repressive more teleological than on sanctions".

${ }^{10}$ M. Duţu, Dreptul mediului, 3 edition, C.H. Beck Publishing House, Bucharest, 2010, pp. 221-222.

${ }^{11}$ N. Popa, Teoria generală a dreptului, C.H. Beck Publishing House, Bucharest, 2002, p. 281.

12 S. Popescu, Fundamentul răspunderii juridice. Câteva remarci, in „Studii de drept”, II volume, Universitas Timisienses Publishing House, Printinf ot University of West, Timişoara, 1998, p. 74.

${ }^{13}$ M. Duţu, Dreptul mediului, C.H. Beck Publishing House,Bucharest, 2007, p. 238.

${ }^{14}$ S. Giova, Responsabilità da danno ambientale. Profili di diritto civile, amministrativo e penale, Edizioni Scientifiche Italiane, Napoli, 2005, p. 138.
} 


\section{D. Ș. Paraschiv}

The contents of some of these instruments provides that liability in environmental law is based on the polluter pays principle, which was held for the first time by the Organization for Economic Cooperation and Development (OECD) in a series of recommendations ${ }^{15}$, since the 1970s. This principle means that the polluter should bear the expenses needed for the prevention and control of pollution to ensure that the environment is in an acceptable condition; according to OECD Recommendation C (74) 223, the cost of these measures should be reflected in the cost of goods and services which cause pollution in production and/or consumption. Subsequently, it was considered that the polluter should also bear the cost of ex post facto, that of the one for remedies; for example, Recommendation C (81) 32 OECD states that the polluter is responsible for "reasonable actions of Repair" if oil spills into the sea.

Institution of liability in international environmental law is based on the principle of State liability for environmental damage, which was enshrined in the Rio Declaration of Principles, 1992 (principle 21) ${ }^{16}$. States have the obligation, according to the written law and custom, to act so as not to affect the rights of other states in this area, principle emphasized in international jurisprudence on environmental law. Thus, for example, the arbitral sentence of 11 March 1941 on the foundry business Trail (U.S. versus Canada), the International Court of Justice held that, under principles of international law and U.S. law, no state has the right to use its territory or permit its use so that the smoke would cause injury to the territory of another state or the properties of individuals within it, if it comes to serious consequences and if the damage is proven by clear and convincing evidence ${ }^{17}$. Arbitral jurisprudence of the International Court of Justice in Environmental Matters, however, is limited by the quasi-absence of coercive means, being also subject to the sovereign will of states.

Each state is required to observe the environment of other states or other areas not related to any national jurisdiction, regardless of activity, according to international environmental law requirements. The new achievements of science and technology development in the context of economic development should be considered for the formulation of new environmental rules, based on existing regulations. Thus, even if there is still no regulation specifically prohibiting the use of nuclear weapons, existing international law regarding the protection and surveillance of the environment still contains important ecological considerations in the regulatory principles and rules of law applicable to conflicts to be taken into account properly in this area also (ICJ, December 20, 1974, nuclear test business New Zealand v France).

According to international regulations on environmental protection, liability for harm caused by an illegal activity per se is often channeled to the person who has decisive economic power over the work that brought environmental damage, a situation which was established at the beginning in the nuclear conventions, such as the 1960 Paris Convention on third party liability in the field of nuclear energy, which entered into force on 04.01.1968, supplemented by the Brussels Convention of 1962, which came into force in 1974; 1963 Vienna Convention on Civil Liability for Nuclear Damage, which entered into force on 12 November 1977, as amended by the Protocol of Vienna in 1977; Joint Protocol on the application of the Vienna Convention and the Paris Convention, adopted in 1988; Protocol on Additional Compensation for Nuclear Damage, adopted in 1977 in Vienna, Brussels Convention of 1962 on the liability of operators of nuclear ships.

\footnotetext{
${ }^{15}$ See Recommendation C (72) 128 of 1972 on the guiding principles of international economic issues of environmental policies, Recommendation C (74) 223 of 1974 on implementing the principle of polluter pays, Recommendation C (89) 88 of 1988 on the application of polluter pays principle to accidental pollution.

${ }^{16}$ Along with states, liability may rest with other subjects of international law.

17 In this regard, see the case Territorial Jurisdiction of the International Commission of the River Oder (United Kingdom of Great Britain and Northern Ireland, Czechoslovakia, Denmark, the French Republic, the German Empire and Sweden against Poland), judgment of 10 September 1929, PCIJ, Series A, No. 23 (http://www.icjcij.org/pcij/serie_A/A_23/74_Commission_internationale_de_1_Oder_Arret.pdf).
} 
Moreover, given the uncertainty about the international responsibility of states, advanced solution in practice, including international conventions for damages, is to transfer the matter to the individual level, as a matter of private international law resolved in domestic courts. In this case fixing the damage goes primarily to the person guilty of violating environmental norms, the state has a residual responsibility ${ }^{18}$.

A particular problem which arises in international environmental law is international liability for damage to common property, "areas beyond national jurisdiction". The need for accountability for environmental assets in certain common areas (seabed beyond national jurisdiction, outer space, Antarctica) results from the provisions of international treaties such as the Treaty banning nuclear weapons experience in the atmosphere, outer space and under water, adopted in 1963; Treaty on Principles Governing the Activities of States in the exploration and use of outer space, including the moon and the celestial bodies, adopted in 1967; Antarctic Treaty of Washington, signed in 1959, entered into force in 1961.

Some international conventions dealing with the Environmental Protection recommend states to adopt national rules to protect the environment in the areas covered by the Convention and sanction acts that affect them. Of these we exemplify: United Nations Convention on the Law of the Sea, signed at Montego Bay (Jamaica) on 10 December 1982; Vienna Convention on the Protection of the Ozone Layer, signed on 22 March 1985; International Convention on preparedness, response and cooperation in case of oil pollution, adopted in London on November 30, 1990; Convention on the Trans boundary Effects of Industrial Accidents, signed in Helsinki, 17 March 1992; United Nations Framework Convention on Climate Change, signed in Rio de Janeiro on May 9, 1992; United Nations Convention to Combat Desertification in those countries experiencing serious drought and/or desertification, particularly in Africa, adopted in Paris on 17 June 1994; Convention on Access to Information, Public Participation in Decision-making and Access to Justice in Environmental Matters, signed in Aarhus in 1998; European Convention on landscapes, adopted on 20 October 2000 in Florence; Convention on Persistent Organic Pollutants, signed in Stockholm on 23 May 2001.

\section{Conclusions}

Classic tool for achieving the requirements of legal rules, the liability has a lower impact on the environment protection and has multiple features.

Internationally, the general trend is that the environment be protected mainly by regulating activities that may affect it in order to prevent injury and less in the way of accountability, due to the particularities of the field. The ecological damage is often permanent, damage is irreversible, and the cost of repair in some cases is exorbitant so that post intervention after the administration of evil, does not give full and effective reparation.

Control and targeted sanctions remain ineffective, as attempts to adopt, based on common law liability, environmental foundations and specific rules have not led to significant achievements in the positive law in this matter. Although attempts to create a specific offense of injury to the environment to suppress in a global manner the eco illicit act, so far have not reached a concrete result, the prospects of a fundamental reform on the main forms of liability for environmental crimes have already emerged ${ }^{19}$.

\section{References}

1. D. Popescu, F. Maxim, Drept internaţional public, Renaissance Publishing House, Bucharest, 2010;

\footnotetext{
${ }^{18}$ M. Duţu, op. cit. p. 241.

${ }^{19}$ M. Duțu, op. cit. p. 222.
} 
2. $\quad$ M. Duţu, Dreptul mediului, 3 edition, C.H. Beck Publishing House, Bucharest, 2010;

3. M. Duţu, Dreptul mediului, C.H. Beck Publishing House,Bucharest, 2007;

4. S. Giova, Responsabilità da danno ambientale. Profili di diritto civile, amministrativo e penale, Edizioni Scientifiche Italiane, Napoli, 2005;

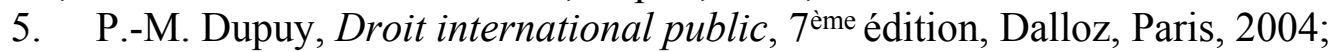

6. N. Popa, Teoria generală a dreptului, C.H. Beck Publishing House, Bucharest, 2002

7. D. Ruzié, Droit international public, $15^{\mathrm{ème}}$ édition, Édition Dalloz, Paris, 2000;

8. M.-L. Larsson, The Law of Environmental Damage: Liability and Reparation, Martinus Nijhoff Publishers, The Hague, 1999;

9. S. Popescu, Fundamentul răspunderii juridice. Câteva remarci, in „Studii de drept”, II volume, Universitas Timisienses Publishing House, Printinf ot University of West, Timişoara, 1998 ;

10. N. N. Constantinescu, Protecţia mediului natural - cerinţă intrinsecă a unei dezvoltări economice moderne, in,,Economistul”, no. 180 of 3-6 April 1992;

11. L. K. Caldwell, International environmental policy: Emergens and dimensions, Second Edition, Duke University Press, Durham, 1990;

12. I. Mihuţ, Autoconducere şi creativitate, Dacia Publishing House, Cluj-Napoca, 1989;

13. I. Avram, D. Şerbănescu, Mediul înconjurător al Terrei încotro?, in RRSI, No.1, JanuaryFebruary 1989;

14. P. Lascoumes, La justice de l'environnement industriel: une place à predre et à inventer, in „Justice”, no. 122, novembre 1988.

This paper has been financially supported within the project entitled "Horizon 2020 Doctoral and Postdoctoral Studies: Promoting the National Interest through Excellence, Competitiveness and Responsibility in the Field of Romanian Fundamental and Applied Economic Research", contract number POSDRU/159/1.5/S/140106. This project is co-financed by European Social Fund through Sectoral Operational Programme for Human Resources Development 2007-2013. Investing in people!'” 